\title{
Methyl Propionate Radical Cation
}

\author{
Jaana M. H. Pakarinen and Pirjo Vainiotalo \\ Department of Chemistry. Univeristy of Joensuu, FIN-80101 Joensuu, Finland
}

\author{
Chris L. Stumpf, Diane T. T eeck, Phillip K. Chou, and Hilkka I. Kenttämaa \\ Department of Chemistry, Purdue University, West Lafayette, Indiana, USA
}

\begin{abstract}
Examination of the reactions of the long-lived ( $>0.5-\mathrm{s}$ ) radical cations of $\mathrm{CD}_{3} \mathrm{CH}_{2} \mathrm{COOCH}_{3}$ and $\mathrm{CH}_{3} \mathrm{CH}_{2} \mathrm{COOCD}_{3}$ indicates that the long-lived, nondecomposing methyl propionate radical cation $\mathrm{CH}_{3} \mathrm{CH}_{2} \mathrm{Cl}(\mathrm{O}) \mathrm{OCH}_{3}^{+\cdot}$ isomerizes to its enol form $\mathrm{CH}_{3} \mathrm{CH}=\mathrm{C}(\mathrm{OH}) \mathrm{OCH}_{3}^{+\cdot}$ $\left(\Delta H_{\text {isomerization }} \simeq-32 \mathrm{kcal} / \mathrm{mol}\right)$ via two different pathways in the gas phase in a Fouriertransform ion cyclotron resonance mass spectrometer. A 1,4-shift of a $\beta$-hydrogen of the acid moiety to the carbonyl oxygen yields the distonic ion $\mathrm{CH}_{2} \mathrm{CH}_{2} \mathrm{C}^{+}(\mathrm{OH}) \mathrm{OCH}_{3}$ that then rearranges to $\mathrm{CH}_{3} \mathrm{CH}=\mathrm{C}(\mathrm{OH}) \mathrm{OCH}_{3}^{+}$, probably by consecutive 1,5- and 1,4-hydrogen shifts. This process is in competition with a 1,4-hydrogen transfer from the alcohol moiety to form another distonic ion, $\mathrm{CH}_{3} \mathrm{CH}_{2} \mathrm{C}^{+}(\mathrm{OH}) \mathrm{OCH}_{2}$, that can undergo a 1,4-hydrogen shift to form $\mathrm{CH}_{3} \mathrm{CH}=\mathrm{C}(\mathrm{OH}) \mathrm{OCH}_{3}^{+}$. Ab initio molecular orbital calculations carried out at the UMP2/6$31 \mathrm{G}^{* *}+$ ZPVE level of theory show that the two distonic ions lie more than $16 \mathrm{kcal} / \mathrm{mol}$ lower in energy than $\mathrm{CH}_{3} \mathrm{CH}_{2} \mathrm{C}(\mathrm{O}) \mathrm{OCH}_{3}^{+*}$. Hence, the first step of both rearrangement processes has a great driving force. The 1,4-hydrogen shift that involves the acid moiety is 3 $\mathrm{kcal} / \mathrm{mol}$ more exothermic $\left(\Delta H_{\text {isomerization }}=-16 \mathrm{kcal} / \mathrm{mol}\right)$ and is associated with a 4$\mathrm{kcal} / \mathrm{mol}$ lower barrier $(10 \mathrm{kcal} / \mathrm{mol})$ than the shift that involves the alcohol moiety. Indeed, experimental findings suggest that the hydrogen shift from the acid moiety is likely to be the favored channel. (J Am Soc Mass Spectrom 1996, 7, 482-489)
\end{abstract}

$\mathrm{E}$ ster radical cations have been of great interest since mass spectrometry experiments [1-6] and ESR studies [7] suggested that these species may spontaneously isomcrize to distonic ions in the gas phase as well as in the condensed phases [1-7]. In some cases, the resulting distonic ion undergoes a further rearrangement to a more stable enol form [3, $5,8]$.

The rate of isomerization of radical cations by hydrogen shifts is largely determined by the size of the transition state. Radical cations are generally stable toward isomerization by 1,2- and 1,3-hydrogen shifts [3]. However, 1,4-hydrogen shifts can occur readily. For example, the long-lived, nonfragmenting methyl formate radical cation $\mathrm{HC}(\mathrm{O}) \mathrm{OCH}_{3}^{+\cdot}$ is known to completely isomerize to $\mathrm{HC}^{+}(\mathrm{OH}) \mathrm{OCH}_{2}[4,5]$. The longlived methyl acetate radical cation $\mathrm{CH}_{3} \mathrm{C}(\mathrm{O}) \mathrm{OCH}_{3}^{+}$. also rearranges by a 1,4-hydrogen shift to yield $\mathrm{CH}_{3} \mathrm{C}^{+}(\mathrm{OH}) \mathrm{OCH}_{2}[5,6]$. However, the resulting distonic ion is unstable toward a further 1,4-hydrogen shift that generates the enol ion $\mathrm{CH}_{2}=\mathrm{C}(\mathrm{OH}) \mathrm{OCH}_{3}^{+}$. [5]; the latter ion corresponds to the global minimum on this potential energy surface $[6,8]$. In an analogous manner, the long-lived methyl propionate radical

Address reprint requests to Dr. Hilkka I. Kenttämaa, Department of Chemistry, Purdue University, West Lafayette, IN 47907-1393. cation $\left.\mathrm{CH}_{3} \mathrm{CH}_{2} \mathrm{ClO}\right) \mathrm{OCH}_{3}^{+} \cdot$ was recently demonstrated [5] to isomerize to the significantly more stable enol form, $\mathrm{CH}_{3} \mathrm{CH}=\mathrm{C}(\mathrm{OH}) \mathrm{OCH}_{3}^{+\cdot}\left(\Delta \mathrm{H}_{\text {isomerization }}=\right.$ $-32 \mathrm{kcal} / \mathrm{mol}$ [9]).

Isomerization of the methyl propionate radical cation can occur by two different pathways that involve 1,4- and 1,5-hydrogen shifts (Scheme I) [5,6a]. A 1,4 -hydrogen transfer from the $\beta$-carbon of the acid moiety to the carbonyl oxygen generates the distonic ion $\mathrm{CH}_{2} \mathrm{CH}_{2} \mathrm{C}^{+}(\mathrm{OH}) \mathrm{OCH}_{3}$. Rearrangement of this ion by a 1,5- and a 1,4-hydrogen shift forms the enol ion. Another conceivable pathway involves an initial 1,4hydrogen shift from the alcohol moiety that results in $\mathrm{CH}_{3} \mathrm{CH}_{2} \mathrm{C}^{+}(\mathrm{OH}) \mathrm{OCH}_{2}$, which then rearranges to the enol ion by a 1,4-hydrogen shift. In spite of the fact that the 1,4-hydrogen shift from the alcohol moiety occurs readily for $\mathrm{CH}_{3} \mathrm{C}(\mathrm{O}) \mathrm{OCH}_{3}^{+\cdot}[5,6 \mathrm{a}]$, isomerization of $\mathrm{CH}_{3} \mathrm{CH}_{2} \mathrm{C}(\mathrm{O}) \mathrm{OCH}_{3}^{+\cdot}$ is thought to occur predominantly by the 1,4-hydrogen shift from the acid moiety (path a, Scheme I) in the microsecond as well as millisecond time frame $[5,6 a]$.

$\mathrm{Ab}$ initio molecular orbital calculations carried out in this work suggest that the distonic ion intermediates $\mathrm{CH}_{2} \mathrm{CH}_{2} \mathrm{C}^{+}(\mathrm{OH}) \mathrm{OCH}_{3}$ and $\mathrm{CH}_{3} \mathrm{CH}_{2} \mathrm{C}^{+}(\mathrm{OH}) \mathrm{OCH}_{2}$ of the two conceivable isomerization pathways of $\mathrm{CH}_{3} \mathrm{CH}_{2} \mathrm{C}(\mathrm{O}) \mathrm{OCH}_{3}^{+\cdot}$ are close in energy and significantly more stable than $\mathrm{CH}_{3} \mathrm{CH}_{2} \mathrm{C}(\mathrm{O}) \mathrm{OCH}_{3}^{+*}$. Hence, 


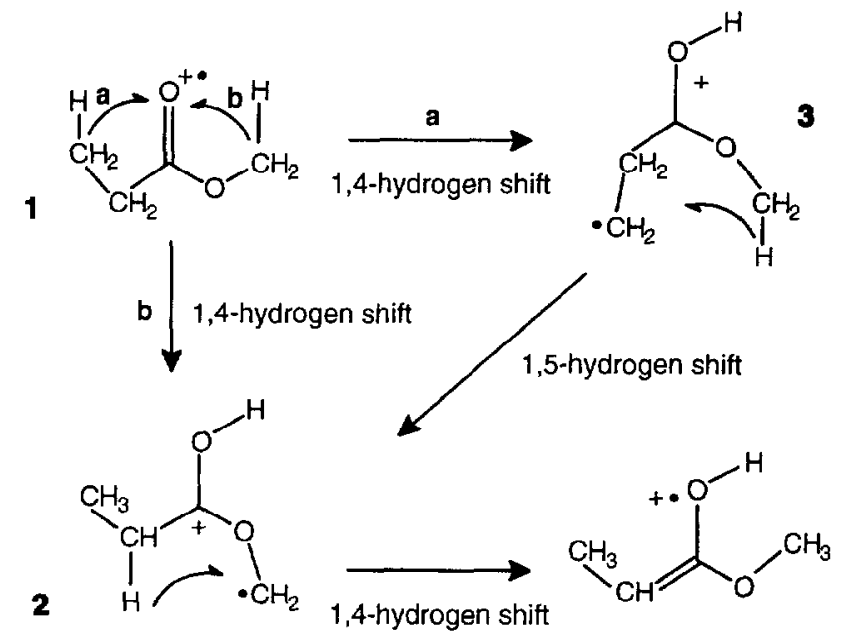

Scheme I.

the intial step of both rearrangement processes has a considerable but similar driving force. The rearrangement to form $\mathrm{CH}_{2} \mathrm{CH}_{2} \mathrm{C}^{+}(\mathrm{OH}) \mathrm{OCH}_{3}$ is calculated to be associated with a somewhat lower energy barrier. These findings inspired an experimental reexamination of the isomerization process of $\mathrm{CH}_{3} \mathrm{CH}_{2} \mathrm{C}(\mathrm{O}) \mathrm{OCH}_{3}^{+}$. The results presented here indicate that the isomerization of the long-lived ion $\mathrm{CH}_{3} \mathrm{CH}_{2} \mathrm{C}(\mathrm{O}) \mathrm{OCH}_{3}^{+\cdot}$ occurs by both mechanisms, that is, that a 1,4-hydrogen shift occurs from the acid as well as from the alcohol moiety in this radical cation.

\section{Experimental Methods}

\section{Calculations}

Standard $a b$ initio molecular orbital calculations were performed with the Gaussian92 program by employing spin-unrestricted Hartree-Fock (UHF) procedures (with SGI R4000 computers). Optimized geometries, harmonic frequencies, and zero-point vibrational energies (ZPVE; this correction is necessary because of finite nuclear motion even at low temperatures) were calculated up to the $6-31 \mathrm{G}^{* *}$ basis set. Because Hartree-Fock calculations are known to overestimate the vibrational frequencies by $10-15 \%$, the zero-point energies were scaled by a factor of 0.9 . The force constant matrices calculated for the stationary points were checked to have the correct number of negative eigenvalues (zero for equilibrium structures and one for transition structures). Single-point energies were calculated for the $6-31 G^{* *}$ geometries by including electron correlation through the use of Meller-Plesset perturbation theory carried out to second order (UMP2/6-31G**//UHF/6-31G**). To check the validity of the single-point calculations, the most stable conformer of each structure (including the two transition states examined) also was optimized at the UMP2/6-31G** level. Unless otherwise indicated, the discussion will refer to calculations carried out at the
UHF $/ 6-31 G^{* *}$ level. The spin-squared expectation values $\left\langle S^{2}\right\rangle$ are within acceptable range and close to the value of 0.75 for the pure spin state.

\section{Experiments}

All the experiments were carried out by using an Extrel Fourier-transform ion cyclotron resonance (FT/ICR) mass spectrometer equipped with a dual-cell reaction chamber (model 2001 Fourier transform mass spectrometer, Extrel ANS, Madison WI) [5] and operated under a 1280 or an Odyssey data station. The dual cell is aligned collinearly with the magnetic field produced by a 3-T superconducting magnet. Each side of the dual cell is independently pumped with a turbomolecular pump (TPU 330, Balzers, Hudson, NH). The nominal base pressure was $<1 \times 10^{-9}$ torr as read by an ion gauge located in each side of the cell. All three trapping plates of the cell were kept at $+2 \mathrm{~V}$ except when otherwise specified.

The neutral reagents were introduced into the FT/ICR cell at a nominal pressure of about $1 \times 10^{-7}$ torr by using a heated batch-inlet system (Extrel) equipped with a variable leak valve or a Varian (Walnut Creek, CA) leak valve. The propionates were ionized by an electron beam. The electron energy $(25-70 \mathrm{eV})$, ionization time $(30-50 \mathrm{~ms})$, and emission current (typically $8 \mu \mathrm{A}$ ) were optimized for each experiment. Immediately after being generated, the propionate ions were transferred from the cell where they were formed into the other cell by grounding the common wall of the two cells (conductance limit) for about $100 \mu \mathrm{s}$. Before ion transfer, all the ions in the receiving cell were removed by application of $-10 \mathrm{~V}$ to the remote trapping plate of that cell for about $5 \mathrm{~ms}$.

After transfer into the other cell, the ions were collisionally cooled for about $500 \mathrm{~ms}$ with argon introduced at a momentary high pressure into the cell through a set of pulsed valves (maximum pressure in the cell about $1 \times 10^{-5}$ torr). The propionate ions were isolated by ejection of unwanted ions from the cell through the use of the stored-waveform inverse Fourier-transform method [10] (by using the Extrel SWIFT module). Care was taken to avoid excitation of the ions of interest. The isolated ions were allowed to react with the neutral base for a variable time period. The primary product ions were identified and their branching ratios were determined based on the reaction product distributions at short reaction times.

The reactions carried out under the conditions used here follow pseudo-first-order kinetics. Hence, a semilogarithmic plot of the relative abundance of the reactant ion as a function of time yielded the experimental reaction rate constants $(k)$. The collision rate constants $\left(k_{\text {collision }}\right)$ were calculated by using a literature procedure [11a]. The reaction efficiencies are given

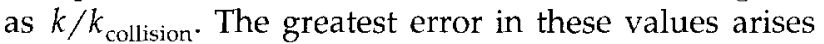
from the estimation of the pressure of the neutral reagent in the cell. The nominal ion gauge pressure 
readings were corrected for the sensitivity of the ion gauges toward each neutral reagent [11b], as well as for the pressure gradient between the ion gauge and the cell [11c].

All the spectra discussed are an average of at least 25 transients obtained by excitation of the ions either by a frequency sweep ("chirp") of $124-\mathrm{V}_{\mathrm{p}-\mathrm{p}}$ amplitude, $2.7-\mathrm{MHz}$ bandwidth, and $3.0-\mathrm{kHz} / \mu \mathrm{s}$ sweep rate, or by using stored-waveform inverse Fourier-transform excitation to yield a $0.5-\mathrm{cm}$ final radius for all ions. The spectra were recorded as $32 k$ data points at a digitizer rate of $5.3 \mathrm{MHz}$ and were subjected to one zero fill before Fourier transformation.

The labeled methyl propionates were synthesized by a literature procedure [12] and checked for purity by NMR, gas chromatography (GC), and mass spectrometry. All other chemicals were obtained commercially and checked for purity by GC and mass spectrometry.

\section{Results and Discussion}

\section{Relative Stabilities of the Different Isomeric Ions $\mathrm{C}_{4} \mathrm{H}_{8} \mathrm{O}_{2}^{+\cdot}$}

Twenty-one different $\mathrm{C}_{4} \mathrm{H}_{8} \mathrm{O}_{2}^{+\cdot}$ structures, which include five different conformers of the methyl propionate radical cation $\mathrm{CH}_{3} \mathrm{CH}_{2} \mathrm{C}(\mathrm{O}) \mathrm{OCH}_{3}^{+\cdot}$ (1) and 16 different conformers of the distonic ions $\mathrm{CH}_{3} \mathrm{CH}_{2} \mathrm{C}^{+}$ $(\mathrm{OH}) \mathrm{OCH}_{2}^{\prime}(2)$ and ${ }^{\circ} \mathrm{CH}_{2} \mathrm{CH}_{2} \mathrm{C}^{+}(\mathrm{OH}) \mathrm{OCH}_{3}$ (3), were examined computationally (Tables 1 and 2 and Figure 1). The geometries were optimized in a stepwise manner up to the UHF /6-31G** level of theory (some of the higher energy conformers do not correspond to an energy minimum; see Table 1). The final relative energies were determined by using a single-point calculation at the UMP2/6-31G $\mathrm{G}^{* *} / \mathrm{UHF} / 6-31 \mathrm{G}^{* *}+$ ZPVE level of theory. The most stable conformations of 1, 2 and 3 (1a, 2a and 3a) and of the two transition structures that connect 1 and 2 (ts12) and 1 and $\mathbf{3}$ (ts13) also were optimized at the UMP2/6-31G** level of theory (Table 2).

Five different low-energy structures were located for $\mathrm{CH}_{3} \mathrm{CH}_{2} \mathrm{C}(\mathrm{O}) \mathrm{OCH}_{3}^{+\cdot}(\mathbf{1 a}-\mathbf{1 e}$; Figure 1). The structures $1 \mathrm{~b}, 1 \mathrm{c}$, and $1 \mathrm{~d}$ have $\mathrm{C}_{1}-\mathrm{C}_{2}-\mathrm{C}_{3}-\mathrm{O}_{1}$ dihedral angle close to 0 or $180^{\circ}$, whereas this angle is 121.3 and $88.8^{\circ}$, respectively, for structures $1 \mathrm{a}$ and $1 \mathrm{e}$ (UHF/6-31G**; the discussion will refer to this level unless otherwise indicated). The energy differences between all these structures are very small (less than $4.3 \mathrm{kcal} / \mathrm{mol}$ ). The charge is located predominantly at the carbonyl carbon (0.855 for 1a) and the highest spin density at the carbonyl oxygen (1.038 for 1a) in all conformers. The geometry of the most stable conformer (1a) changed very little from the UHF $/ 6-31 \mathrm{G}^{* *}$ level to the electron correlation level UMP2/6-31G** (Figure 1).

Eight different low energy conformers of the distonic ions $\mathrm{CH}_{3} \mathrm{CH}_{2} \mathrm{C}^{+}(\mathrm{OH}) \mathrm{OCH}_{2}$ (2) and
$\mathrm{CH}_{2} \mathrm{CH}_{2} \mathrm{C}^{-}(\mathrm{OH}) \mathrm{OCH}_{3}$ (3) also were examined. At the lowest level of theory (3-21G), eight of the 16 distonic structures studied were calculated to be less stable than $\mathrm{CH}_{3} \mathrm{CH}_{2} \mathrm{C}(\mathrm{O}) \mathrm{OCH}_{3}^{+\cdot}$ (1a). However, at the UMP2 $/ 6-31 G^{* * *} / /$ UHF $/ 6-31 G^{* *}+$ ZPVE, all the distonic structures were found to be significantly more stable than 1a. Inclusion of electron correlation (UMP2 $/ 6-31 \mathrm{G}^{* *} / / \mathrm{UHF} / 6-31 \mathrm{G}^{* *}$ ) had the greatest lowering effect on the relative energies of the distonic ions. At this level of theory, the most stable conformer of the distonic ion ${ }^{\circ} \mathrm{CH}_{2} \mathrm{CH}_{2} \mathrm{C}^{+}(\mathrm{OH}) \mathrm{OCH}_{3}$ (3a) lies $18.8 \mathrm{kcal} / \mathrm{mol}$ lower in energy than $\mathrm{CH}_{3} \mathrm{CH}_{2}$ $\mathrm{C}(\mathrm{O}) \mathrm{OCH}_{3}^{+\cdot}(1 \mathrm{a})$ and $3.6 \mathrm{kcal} / \mathrm{mol}$ lower in energy than the most stable structure found for $\mathrm{CH}_{3} \mathrm{CH}_{2} \mathrm{C}^{+}(\mathrm{OH}) \mathrm{OCH}_{2}^{-}$(2a). These values did not change appreciably when the geometries were optimized at the UMP2/6-31G** level: the ion ${ }^{-} \mathrm{CH}_{2} \mathrm{CH}_{2} \mathrm{C}^{+}(\mathrm{OH}) \mathrm{OCH}_{3}$ (3a) was found to lie 19.4 $\mathrm{kcal} / \mathrm{mol}$ lower in energy than $\mathrm{CH}_{3} \mathrm{CH}_{2} \mathrm{C}(\mathrm{O}) \mathrm{OCH}_{3}^{+}$. (1a) and $3.4 \mathrm{kcal} / \mathrm{mol}$ lower in energy than $\mathrm{CH}_{3} \mathrm{CH}_{2} \mathrm{C}^{+}(\mathrm{OH}) \mathrm{OCH}_{2}^{-}(2 \mathrm{a})$ at the UMP2/6-31G** + ZPVE level of theory.

The local structure of the $\mathrm{CH}_{3} \mathrm{O}$-groups in $\left.\mathrm{CH}_{3} \mathrm{CH}_{2} \mathrm{ClO}\right) \mathrm{OCH}_{3}^{\prime}$ (1) and ${ }^{\circ} \mathrm{CH}_{2} \mathrm{CH}_{2} \mathrm{C}^{+}(\mathrm{OH}) \mathrm{OCH}_{3}$ (3) is essentially identical. However, the radical site in ${ }^{\circ} \mathrm{CH}_{2} \mathrm{CH}_{2} \mathrm{C}^{+}(\mathrm{OH}) \mathrm{OCH}_{3}$ (3a) is reflected by a remarkably short $\mathrm{CH}_{2}-\mathrm{CH}_{2}$ bond (at the UMP2/6-31G** level: 3a: $1.496 \AA$ versus $\mathrm{CH}_{3}-\mathrm{CH}_{2}$ in 1a: $1.536 \AA$ and $\mathrm{CH}_{3}-\mathrm{CH}_{2}$ in 2a: $1.524 \AA$ ). The highest atomic spin density in the ion 3a is located at the $\mathrm{CH}_{2}-\mathrm{C}$ (C1: 1.212 at the UMP2/6-31G** level). Most of the positive charge is at the carbonyl carbon (C3: 0.854).

The $\mathrm{CH}_{3} \mathrm{CH}_{2}$ group in the ions $\mathrm{CH}_{3} \mathrm{CH}_{2}$ $\mathrm{C}^{+}(\mathrm{OH}) \mathrm{OCH}_{2}^{-}$(2) and $\mathrm{CH}_{3} \mathrm{CH}_{2} \mathrm{C}(\mathrm{O}) \mathrm{OCH}_{3}^{+\cdot}$ (1) is essentially unaffected by the structure of the rest of the respective ions. However, stabilization of the radical site by the oxygen atom in $\mathrm{CH}_{3} \mathrm{CH}_{2} \mathrm{C}^{+}(\mathrm{OH}) \mathrm{OCH}_{2}^{-}$(2a) leads to a very short $\mathrm{O}-\mathrm{CH}_{2}^{\circ}$ bond [at the UMP2/6$31 \mathrm{G}^{* *}$ level, $2 \mathrm{a}(1.403 \AA)$ versus $\mathrm{O}-\mathrm{CH}_{3}$ in $\mathbf{1 a}(1.492$ $\AA$ ) and $\mathrm{O}-\mathrm{CH}_{3}$ in $3 \mathbf{a}(1.484 \AA)$ ] and a relatively long $\mathrm{C}^{+}(\mathrm{OH})-\mathrm{O}$ bond [at the UMP2/6-31G** level, 2a $(1.286 \AA)$ versus $\mathrm{C}(\mathrm{O})-\mathrm{O}$ in $\mathbf{1 a}(1.275 \AA)$ and $\mathrm{C}(\mathrm{OH})-\mathrm{O}$ in 3a $(1.273 \AA)$ ]. The atomic spin density in 2a is located at the $\mathrm{CH}_{2}-\mathrm{C}(\mathrm{C} 4: 1.173$ at the UMP2/6-31G** level) and the greatest positive charge is located at the carbonyl carbon (C3: 0.870). The ion 1a also has the greatest positive charge at this carbon (C3: $0.868)$, but the greatest spin density is located at the oxygen atom (1.038 at the UMP2/6-31G ${ }^{* *}$ level).

\section{Isomerization Mechanism}

The relative energies of the species possibly involved in the isomerization of $\mathrm{CH}_{3} \mathrm{CH}_{2} \mathrm{C}(\mathrm{O}) \mathrm{OCH}_{3}^{+\cdot}$ to $\mathrm{CH}_{3} \mathrm{CH}=\mathrm{C}(\mathrm{OH}) \mathrm{OCH}_{3}^{+\cdot}$ are illustrated in Figure 2 [based on the computational results discussed in the foregoing text and the earlier reported [9] heats of formation of $\mathrm{CH}_{3} \mathrm{CH}_{2} \mathrm{C}(\mathrm{O}) \mathrm{OCH}_{3}^{+}$and $\mathrm{CH}_{3}$ $\mathrm{CH}=\mathrm{C}(\mathrm{OH}) \mathrm{OCH}_{3}^{+\cdot}$. Both isomerization pathways are 
Table 1. Calculated total energies (Hartrees) and relative energies (kilocalories per mole, in parentheses), zero-point vibrational energies $\left(\mathrm{ZPVE}^{\mathrm{a}}\right.$ ), and final relative energies for some $\left[\mathrm{C}_{4} \mathrm{H}_{8} \mathrm{O}_{2}\right]^{+}$isomers

\begin{tabular}{|c|c|c|c|c|c|c|c|}
\hline Structure & $\mathrm{UHF} / 3-21 \mathrm{G}$ & $\mathrm{UHF} / 6-31 \mathrm{G}$ & $\mathrm{UHF} / 6-31 \mathrm{G}^{*}$ & UHF/6-31G** & $\begin{array}{l}\text { UMP2/6-31G**// } \\
\text { UHF } / 6-31 G^{* *}\end{array}$ & $\begin{array}{l}\text { ZPVE }^{\mathrm{a}} \\
(\mathrm{kcal} / \mathrm{mol})\end{array}$ & $\begin{array}{l}E_{\mathrm{rel}}^{\mathrm{b}} \\
(\mathrm{kcal} / \mathrm{mol})\end{array}$ \\
\hline $1 \mathbf{a}$ & $\begin{array}{l}-303.86520 \\
(0)\end{array}$ & $\begin{array}{l}-305.41507 \\
(0)\end{array}$ & $\begin{array}{l}-305.56211 \\
(0)\end{array}$ & $\begin{array}{l}-305.57535 \\
\text { (o) }\end{array}$ & $\begin{array}{l}-306.43345 \\
(0)\end{array}$ & 70.92 & 0 \\
\hline $1 b^{c}$ & $\begin{array}{l}-303.86517 \\
(0.02)\end{array}$ & $\begin{array}{l}-305.41476 \\
(0.19)\end{array}$ & $\begin{array}{l}-305.56154 \\
(0.36)\end{array}$ & $\begin{array}{l}-305.57487 \\
(0.30)\end{array}$ & $\begin{array}{l}-306.43253 \\
(0.58)\end{array}$ & 70.81 & 0.47 \\
\hline $1 \mathrm{c}$ & $\begin{array}{l}-303.86441 \\
(0.50)^{c}\end{array}$ & $\begin{array}{l}-305.41449 \\
(0.36)\end{array}$ & $\begin{array}{l}-305.56136 \\
(0.47)\end{array}$ & $\begin{array}{l}305.57472 \\
(0.40)\end{array}$ & $\begin{array}{l}-306.43176 \\
(1.06)\end{array}$ & 70.75 & 0.89 \\
\hline 1d & $\begin{array}{l}-303.86128 \\
(2.46)\end{array}$ & $\begin{array}{l}-305.41132 \\
(2.35)\end{array}$ & $\begin{array}{l}-305.55752 \\
(2.88)\end{array}$ & $\begin{array}{l}-305.57083 \\
(2.84)\end{array}$ & $\begin{array}{l}-306.42727 \\
(3.88)\end{array}$ & 70.94 & 3.90 \\
\hline $1 e$ & $\begin{array}{l}-303.86103 \\
(2.62)\end{array}$ & $\begin{array}{l}-305.41099 \\
(2.56)\end{array}$ & $\begin{array}{l}-305.55688 \\
(3.28)\end{array}$ & $\begin{array}{l}-305.57004 \\
(3.33)\end{array}$ & $\begin{array}{l}-306.42701 \\
(4.04)\end{array}$ & 71.16 & 4.28 \\
\hline $2 a$ & $\begin{array}{l}-303.86788 \\
(-1.68)\end{array}$ & $\begin{array}{l}-303.41875 \\
(-2.31)\end{array}$ & $\begin{array}{l}-305.56399 \\
(-1.18)\end{array}$ & $\begin{array}{l}-305.58311 \\
(-4.87)\end{array}$ & $\begin{array}{l}-306.45686 \\
(-14.69)\end{array}$ & 70.37 & -15.24 \\
\hline $2 b$ & $\begin{array}{l}-303.86763 \\
(-1.52)\end{array}$ & $\begin{array}{l}-305.41811 \\
(-1.91)\end{array}$ & $\begin{array}{l}-305.56354 \\
(-0.90)\end{array}$ & $\begin{array}{l}-305.58278 \\
(-4.66)\end{array}$ & $\begin{array}{l}-306.45641 \\
(-14.41)\end{array}$ & 70.34 & -14.99 \\
\hline $2 c$ & $\begin{array}{l}-303.86716 \\
(-1.23)\end{array}$ & $\begin{array}{l}-305.41695 \\
(-1.18)\end{array}$ & $\begin{array}{l}-305.56272 \\
(-0.38)\end{array}$ & $\begin{array}{l}-305.58176 \\
(-4.0)\end{array}$ & $\begin{array}{l}-306.45486 \\
(-13.43)\end{array}$ & 70.49 & -13.87 \\
\hline $2 d$ & $\begin{array}{l}-303.86640 \\
(-0.75)\end{array}$ & $\begin{array}{l}-305.41655 \\
(-0.93)\end{array}$ & $\begin{array}{l}-305.56203 \\
(-0.05)\end{array}$ & $\begin{array}{l}-305.58090 \\
(-3.48)\end{array}$ & $\begin{array}{l}-306.45383 \\
(-12.79)\end{array}$ & 70.70 & -13.01 \\
\hline $2 e$ & $\begin{array}{l}-303.86112 \\
(2.56)\end{array}$ & $\begin{array}{l}-305.41123 \\
(2.41)^{c}\end{array}$ & $\begin{array}{l}-305.55927 \\
(1.78)\end{array}$ & $\begin{array}{l}-305.57822 \\
(-1.80)\end{array}$ & $\begin{array}{l}-306.45138 \\
(-11.25)\end{array}$ & 70.33 & -11.84 \\
\hline $2 f$ & $\begin{array}{l}-303.86121 \\
(2.50)\end{array}$ & $\begin{array}{l}-305.41145 \\
(2.27)\end{array}$ & $\begin{array}{l}-305.55924 \\
(1.80)^{c}\end{array}$ & $\begin{array}{l}-305.57824 \\
(-1.81)^{c}\end{array}$ & $\begin{array}{l}-306.45118 \\
(-11.13)\end{array}$ & 70.14 & -11.91 \\
\hline $2 \mathrm{~g}$ & $\begin{array}{l}-303.85841 \\
(4.26)\end{array}$ & $\begin{array}{l}-305.40802 \\
(4.42)\end{array}$ & $\begin{array}{l}-305.55691 \\
(3.26)\end{array}$ & $\begin{array}{l}-305.57594 \\
(-0.37)\end{array}$ & $\begin{array}{l}-306.45016 \\
(-10.49)\end{array}$ & 70.54 & -10.87 \\
\hline $2 \mathrm{~h}$ & $\begin{array}{l}-303.85682 \\
(5.26)\end{array}$ & $\begin{array}{l}-305.40650 \\
(5.38)\end{array}$ & $\begin{array}{l}305.55524 \\
(4.31)\end{array}$ & $\begin{array}{l}305.57422 \\
(0.71)\end{array}$ & $\begin{array}{l}306.44787 \\
(-9.05)\end{array}$ & 70.69 & -9.28 \\
\hline $3 \mathbf{a}$ & $\begin{array}{l}-303.87486 \\
(-6.06)\end{array}$ & $\begin{array}{l}-305.42766 \\
(-7.90)\end{array}$ & $\begin{array}{l}-305.57210 \\
(-6.27)\end{array}$ & $\begin{array}{l}-305.59091 \\
(-9.76)\end{array}$ & $\begin{array}{l}-306.46255 \\
(-18.26)\end{array}$ & 70.39 & -18.79 \\
\hline $3 b$ & $\begin{array}{l}-303.87125 \\
(-3.80)\end{array}$ & $\begin{array}{l}-305.42381 \\
(-5.48)\end{array}$ & $\begin{array}{l}-305.56846 \\
(-3.98)\end{array}$ & $\begin{array}{l}-305.58746 \\
(-7.60)\end{array}$ & $\begin{array}{l}-306.45835 \\
(-15.62)\end{array}$ & 70.13 & -16.42 \\
\hline $3 c$ & $\begin{array}{l}-303.87049 \\
(-3.32)\end{array}$ & $\begin{array}{l}-305.42274 \\
(-4.81)\end{array}$ & $\begin{array}{l}-305.56705 \\
(-3.10)\end{array}$ & $\begin{array}{l}-305.58580 \\
(-6.56)\end{array}$ & $\begin{array}{l}-306.45745 \\
(-15.06)\end{array}$ & 70.48 & -15.50 \\
\hline $3 d$ & $\begin{array}{l}-303.87003 \\
(-3.03)\end{array}$ & $\begin{array}{l}-305.42209 \\
(-4.41)\end{array}$ & $\begin{array}{l}-305.56648 \\
(-2.74)\end{array}$ & $\begin{array}{l}-305.58537 \\
(-6.29)\end{array}$ & $\begin{array}{l}-306.45626 \\
(-14.31)\end{array}$ & 70.18 & -15.05 \\
\hline $3 e$ & $\begin{array}{l}-303.86373 \\
(0.92)\end{array}$ & $\begin{array}{l}-305.41529 \\
(-0.14)\end{array}$ & $\begin{array}{l}-305.56276 \\
(-0.41)\end{array}$ & $\begin{array}{l}-305.58159 \\
(-3.92)\end{array}$ & $\begin{array}{l}-306.45421 \\
(-13.03)\end{array}$ & 70.42 & -13.53 \\
\hline $3 f$ & $\begin{array}{l}-303.86359 \\
(1.01)^{d}\end{array}$ & $\begin{array}{l}-305.41606 \\
(-0.62)\end{array}$ & $\begin{array}{l}-305.56272 \\
(-0.38)\end{array}$ & $\begin{array}{l}-305.58148 \\
(-3.85)\end{array}$ & $\begin{array}{l}-306.45309 \\
(-12.32)\end{array}$ & 70.28 & -12.97 \\
\hline $3 g$ & $\begin{array}{l}-303.86377 \\
(0.90)\end{array}$ & $\begin{array}{l}-305.41594 \\
(-0.55)\end{array}$ & $\begin{array}{l}-305.56208 \\
(0.02)\end{array}$ & $\begin{array}{l}-305.58102 \\
(-3.56)\end{array}$ & $\begin{array}{l}-306.45170 \\
(-11.45)\end{array}$ & 69.94 & -12.43 \\
\hline $3 \mathrm{~h}$ & $\begin{array}{l}-303.85979 \\
(3.39)\end{array}$ & $\begin{array}{l}-305.41156 \\
(2.20)\end{array}$ & $\begin{array}{l}-305.55902 \\
(1.94)\end{array}$ & $\begin{array}{l}-305.57791 \\
(-1.61)\end{array}$ & $\begin{array}{l}-306.45016 \\
(-10.49)\end{array}$ & 70.41 & -11.00 \\
\hline
\end{tabular}

${ }^{a}$ At the UHF $/ 6-31 \mathrm{G}^{* *}$ level and scaled by a factor of 0.9

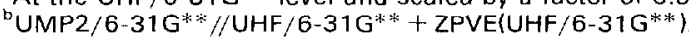

${ }^{\mathrm{c}}$ Number of imaginary frequencies $=1$.

${ }^{d}$ Number of imaginary frequencies $=4$

initiated by a highly exothermic (16-20 kcal/mol) 1,4hydrogen transfer (paths a and $\mathbf{b}$; Scheme I). Path a involves an energetically more favorable transition structure (by $3 \mathrm{kcal} / \mathrm{mol}$; ts 13 , Table 2 ) and generates the more stable intermediate $\mathrm{CH}_{2} \mathrm{CH}_{2} \mathrm{C}^{+}(\mathrm{OH}) \mathrm{OCH}_{3}$ (3). The resulting distonic ion $\mathrm{CH}_{2} \mathrm{CH}_{2} \mathrm{C}^{+}(\mathrm{OH}) \mathrm{OCH}_{3}$ can rearrange to $\mathrm{CH}_{3} \mathrm{CH}_{2} \mathrm{C}^{+}(\mathrm{OH}) \mathrm{OCH}_{2}$ (2) via a favorable six-membered transition state, but this step is slightly endothermic $\left(\Delta H_{\text {reaction }}=+4 \mathrm{kcal} / \mathrm{mol}\right)$. Path b would directly generate the distonic ion $\mathrm{CH}_{3} \mathrm{CH}_{2} \mathrm{C}^{+}(\mathrm{OH}) \mathrm{OCH}_{2}$ (2, Scheme I) but that would involve a slightly higher energy transition structure (ts12, Table 2). The final step in both channels involves the isomerization of $\mathrm{CH}_{3} \mathrm{CH}_{2} \mathrm{C}^{+}(\mathrm{OH}) \mathrm{OCH}_{2}$ to $\mathrm{CH}_{3} \mathrm{CH}=\mathrm{C}(\mathrm{OH}) \mathrm{OCH}_{3}^{+\cdot}$ by an exothermic 1,4-hydrogen shift. Based on these considerations, it is not obvious that isomerization of $\mathrm{CH}_{3} \mathrm{CH}_{2} \mathrm{C}(\mathrm{O}) \mathrm{OCH}_{3}^{+\cdot}$ occurs exlusively via pathway a. Therefore, the isomerization mechanism was reexamined experimentally.

An earlier study demonstrated that $\mathrm{CH}_{3} \mathrm{CH}=$ $\mathrm{C}(\mathrm{OH}) \mathrm{OCH}_{3}$ is a Brönsted acid and readily transfers the hydroxylic hydrogen as a proton to many basic reagents [5]. Hence, examination of suilably labeled methyl propionate ions with bases should allow one to distinguish between the two mechanisms [5, 6a] (a and b. Scheme I) because they involve transfer of a differ- 
Table 2. The energies (Hartrees), relative energies in parentheses (kilocalories per mole), and zero-point vibrational energies (ZPVE) calculated at electron correction level

\begin{tabular}{clll}
\hline Structure & UMP2/6-31G** & ZPVE $^{\text {a }}(\mathrm{kcal} / \mathrm{mol})$ & UMP2/6-31G** + ZPVE \\
\hline \hline $1 \mathrm{a}$ & -306.43549 & 68.16 & -306.32687 \\
& $(0)$ & & $(0)$ \\
$2 \mathrm{a}$ & -306.45981 & 67.44 & -306.35234 \\
& $(-15.26)$ & & $(-15.98)$ \\
$3 a$ & -306.46551 & 67.62 & -306.35775 \\
& $(-18.83)$ & & $(-19.38)$ \\
$\operatorname{tr} 12$ & -306.40920 & 65.79 & -306.30435 \\
$\operatorname{tr} 13$ & $(16.50)$ & & $(14.13)$ \\
& $(1606.40920$ & 66.02 & -306.31035 \\
& $(16.50)$ & & $(10.36)$ \\
\hline
\end{tabular}

${ }^{a}$ Calculated at UMP $2 / 6-31 \mathrm{G}^{* *}$ level of theory and scaled by a factor of 0.9 .

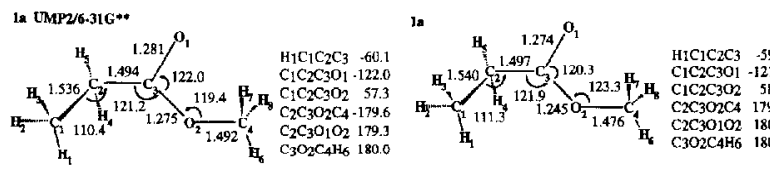

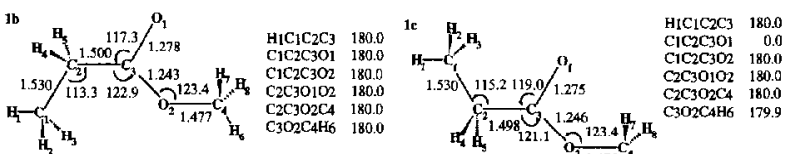

d

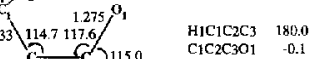

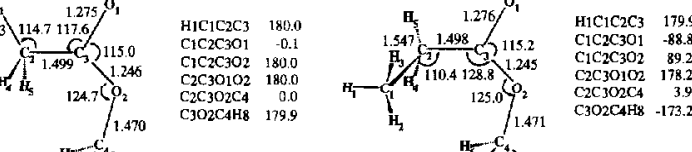

24. UMP2/6-31G"*
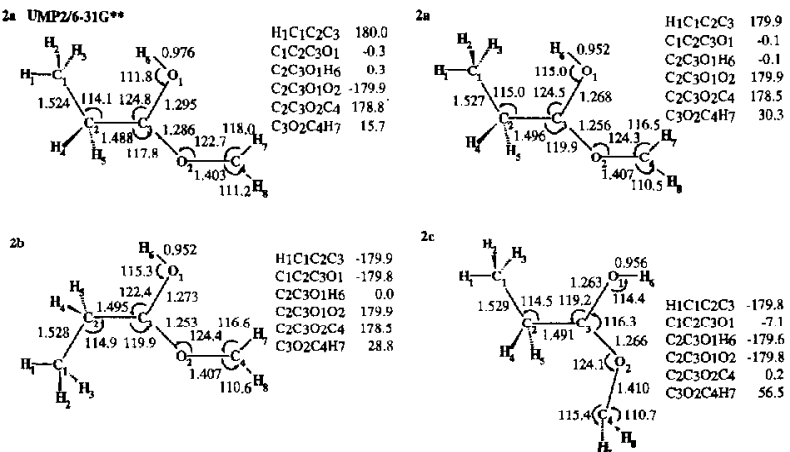

2al
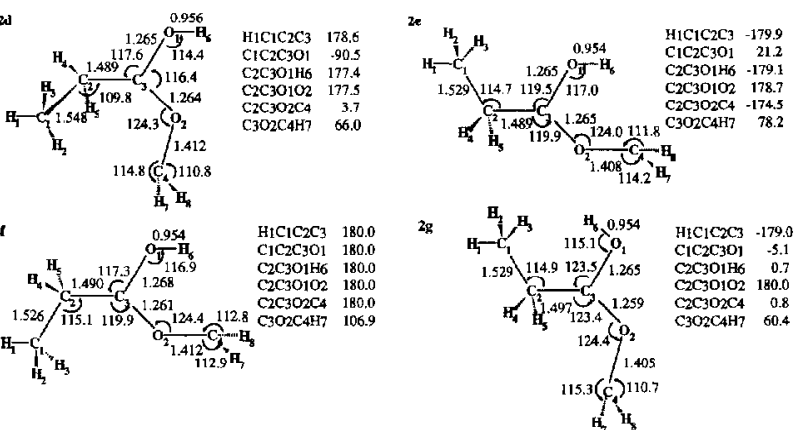
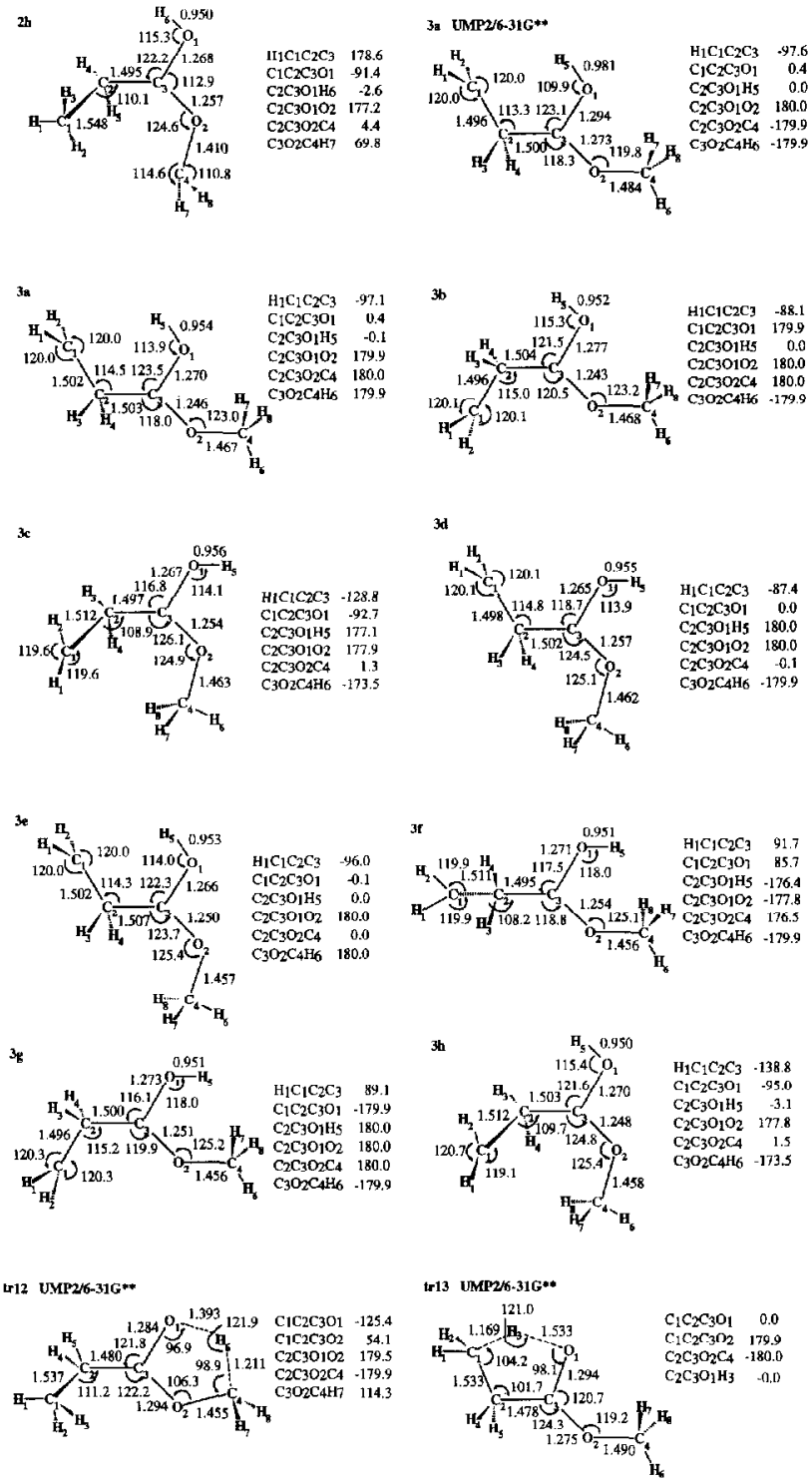

Figure 1. The UHF $/ 6-31 \mathrm{G}^{* *}$ optimized and UMP2/6-31G** optimized structures (the latter have been marked). Dihedral angles are specified alongside each structure. 


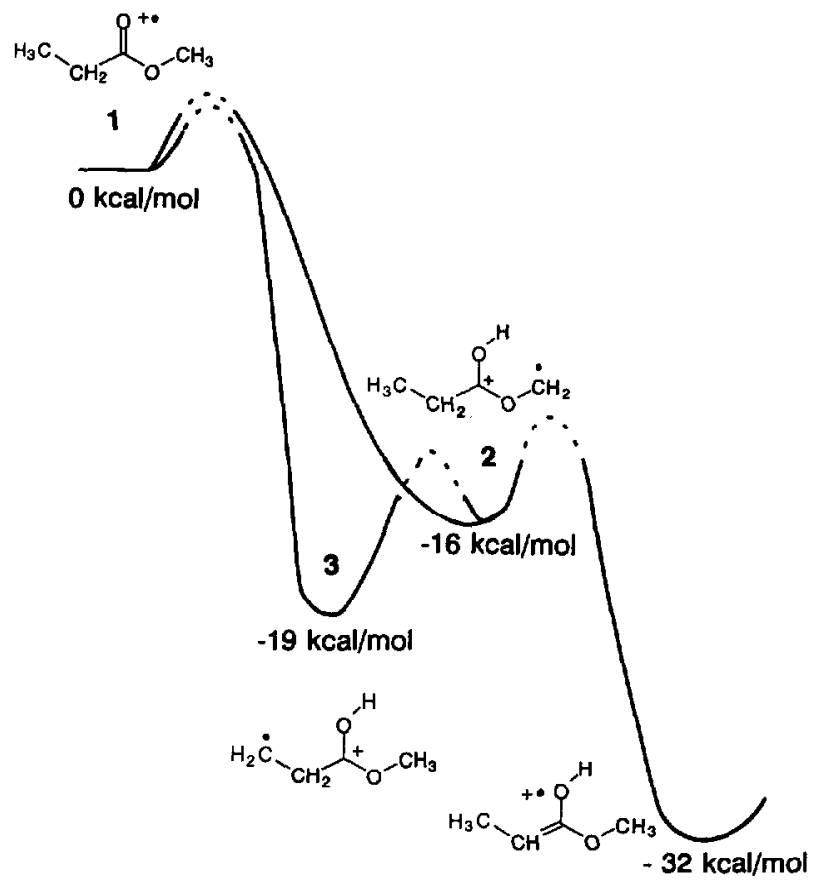

Figure 2. Relative energies of the isomeric methyl propionate ions.

ent hydrogen atom to the acidic site (carbonyl oxygen). The radical cations of the labeled compounds $\mathrm{CD}_{3} \mathrm{CH}_{2} \mathrm{COOCH}_{3}$ and $\mathrm{CH}_{3} \mathrm{CH}_{2} \mathrm{COOCD}_{3}$ were selected for this study. If isomerization via pathway a dominates, the isomerized radical cation of $\mathrm{CD}_{3} \mathrm{CH}_{2} \mathrm{COOCH}_{3}$ will donate $\mathrm{D}^{+}$to a base whereas the cation formed from $\mathrm{CH}_{3} \mathrm{CH}_{2} \mathrm{COOCD}_{3}$ will donate $\mathrm{H}^{+}$(Scheme II). The reverse is true for pathway $b$ (Scheme II). H/D scrambling during isomerization is not likely to hamper the interpretation of the results

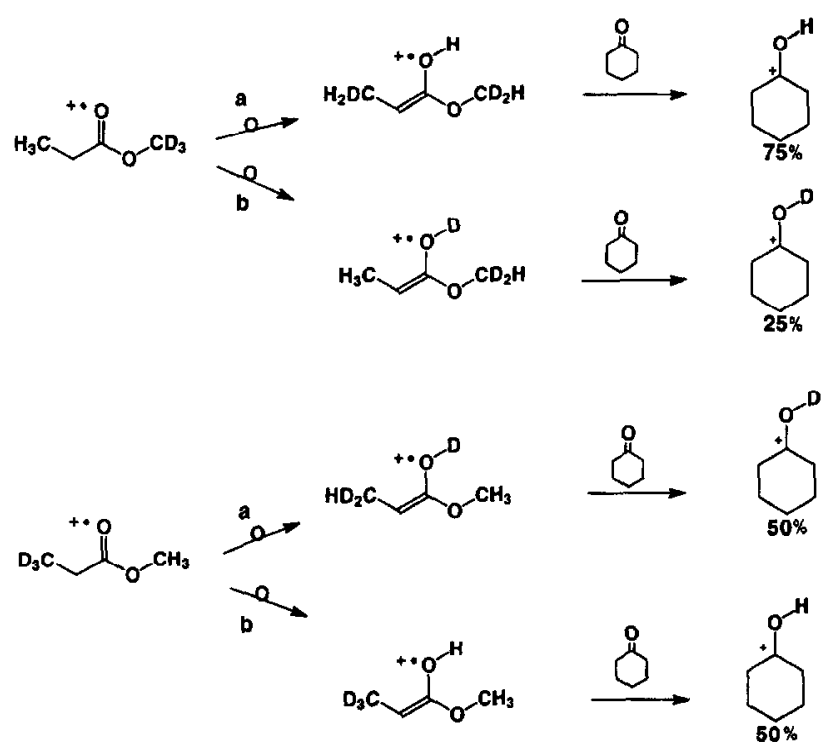

Scheme II.
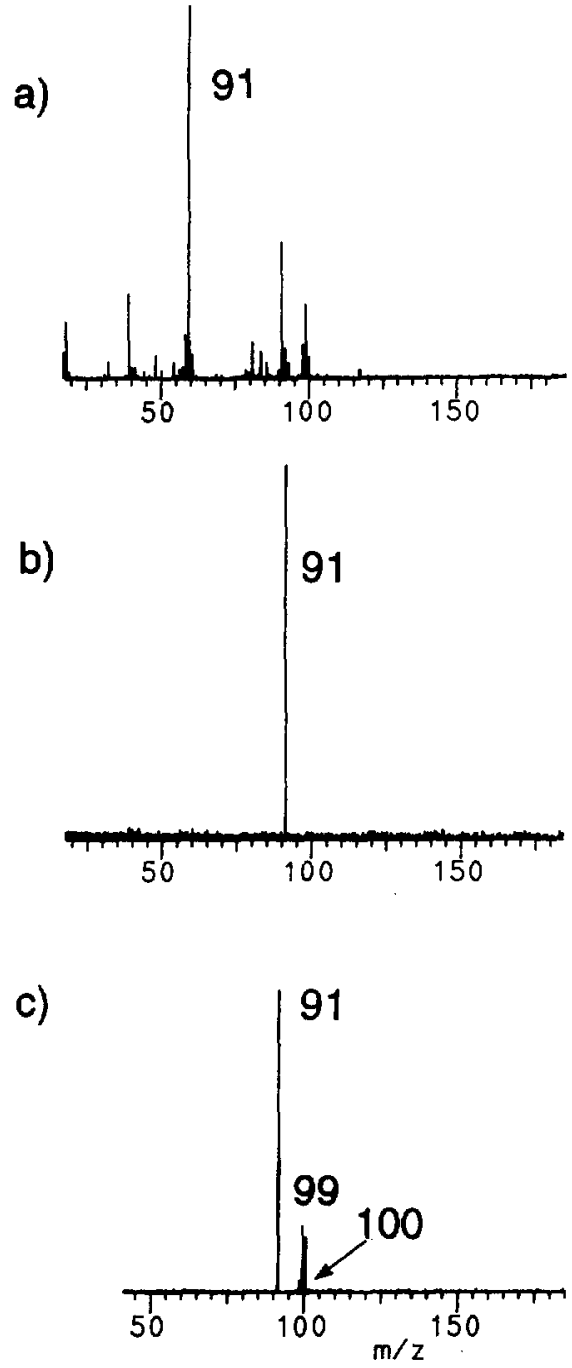

Figure 3. (a) $\mathrm{CD}_{3} \mathrm{CH}_{2} \mathrm{C}(\mathrm{O}) \mathrm{OCH}_{3}$ (nominal pressure $5.6 \times 10^{-7}$ torr) was ionized by $70-\mathrm{eV}$ electron impact in one side of the dual cell. The resulting ions were transferred into the other side of the cell, collisionally cooled with argon, and detected. (b) The radical cation of $\left.\mathrm{CD}_{3} \mathrm{CH}_{2} \mathrm{ClO}\right) \mathrm{OCH}_{3}(\mathrm{~m} / z$ 91) was isolated and (c) allowed to react for $800 \mathrm{~ms}$ with cyclohexanone (nominal pressure $1 \times 10^{-7}$ torr) for a variable period of time. Nearly equal amounts of $\mathrm{H}^{+}$transfer $(m / z 99)$ and $\mathrm{D}^{+}$transfer $(m / z$ 100) occur to cyclohexanone. The product branching ratio is independent of the reaction time used.

because the first step in both isomerization pathways is highly exothermic and likely to be irreversible. Inasmuch as this step determines which hydrogen atom is transferred to the acidic site, $\mathrm{H} / \mathrm{D}$-scrambling that occurs after this step does not affect the results.

The labeled compounds $\mathrm{CD}_{3} \mathrm{CH}_{2} \mathrm{COOCH}_{3}$ and $\mathrm{CH}_{3} \mathrm{CH}_{2} \mathrm{COOCD}_{3}$ were introduced into one side of the dual cell reaction chamber and ionized with an electron beam. The resulting ions were transferred into the other side of the dual cell (Figure 3a), where the methyl propionate radical cation was isolated (Figure $3 b$ ) and allowed to react with cyclohexanone (Figure 3c). Both radical cations were found to readily transfer $D^{+}$ and $\mathrm{H}^{+}$to cyclohexanone (about $30 \%$ of the collisions 
lead to a reaction).* The same is true for ammonia. These findings conclusively demonstrate that both pathways $\mathbf{a}$ and $\mathbf{b}$ must be operational during isomerization of $\mathrm{CH}_{3} \mathrm{CH}_{2} \mathrm{C}(\mathrm{O}) \mathrm{OCH}_{3}^{+}$.

The differently labeled radical cations were found to transfer $\mathrm{H}^{+}$and $\mathrm{D}^{+}$to cyclohexanone in different ratios: the radical cation of $\mathrm{CD}_{3} \mathrm{CH}_{2} \mathrm{COOCH}_{3}$ donates $\mathrm{D}^{+}$and $\mathrm{H}^{+}$in about 0.5:0.5 ratio (Figure $3 \mathrm{c}$ ), whereas for $\mathrm{CH}_{3} \mathrm{CH}_{2} \mathrm{COOCD}_{3}$, the ratio is 0.25:0.75 (Scheme II). However, these data cannot be used to derive the relative rates of the two isomerization reactions because these reactions are likely to be associated with significant [13], but currently unknown, kinetic isotope effects (the kinetic isotope effects associated with the deprotonation reactions are likely to be very small and can be ignored*).

A normal primary kinetic isotope effect in the first step of the two isomerization processes would slow down isomerization of the labeled ion $\mathrm{CD}_{3} \mathrm{CH}_{2}$ $\mathrm{COOCH}_{3}^{+\cdot}$ via pathway a because this pathway involves transfer of a deuterium atom instead of a hydrogen atom. Hence, pathway a would be less favored for this ion than for the undeuterated ion. The situation is reversed for $\mathrm{CH}_{3} \mathrm{CH}_{2} \mathrm{COOCD}_{3}^{+}$: a normal primary kinetic isotope effect would facilitate the reaction via pathway a relative to pathway $\mathbf{b}$.

A primary kinetic isotope effect $k_{\mathrm{H}} / k_{\mathrm{D}}=2.2-3.0$ (depends on ion energy) has been measured earlier for an isomerization analogous to the first step in pathway a: 1,4-hydrogen shift from the acid moiety to the carbonyl oxygen in methyl isobutyrate radical cation $\left(\mathrm{CH}_{3}\right)_{2} \mathrm{CHC}(\mathrm{O}) \mathrm{OCH}_{3}^{+\cdot}$ to yield $\mathrm{CH}_{2} \mathrm{C}\left(\mathrm{CH}_{3}\right) \mathrm{CHC}(\mathrm{OH}) \mathrm{OCH}{ }_{3}^{+\cdot}$ [13]. If a kinetic isotope effect of this magnitude (2.0) also applies for the rearrangement of $\mathrm{CH}_{3} \mathrm{CH}_{2} \mathrm{C}(\mathrm{O}) \mathrm{OCH}_{3}^{+\cdot}$ by the two 1,4-hydrogen shifts in pathways $\mathbf{a}$ and $\mathbf{b}$, then the transfer ratio $\mathrm{D}^{+}: \mathrm{H}^{+}=0.5: 0.5$ observed for the radical cation generated from $\mathrm{CD}_{3} \mathrm{CH}_{2} \mathrm{COOCH}_{3}$ suggests that pathway a must be favored by a factor of 2 for the undeuterated ion. If this suggestion is valid, the ion generaled from $\mathrm{CH}_{3} \mathrm{CH}_{2} \mathrm{COOCD}_{3}$ should show a ratio $\mathrm{H}^{+}: \mathrm{D}^{+}=4: 1$, or $0.8: 0.2$. Within experimental error, this is what was measured $(0.75: 0.25)$.

Obviously, the preceding analysis involves adjustment two unknown parameters - the kinetic isotope effect and the relative rates of the two rearrangement processes $\mathbf{a}$ and $\mathbf{b}$ - and hence cannot yield any quantitatively meaningful conclusions. However, this excercise shows that the results obtained are reasonable if both isomerization pathways are operative, if a normal primary kinetic isotope effect is associated with the first hydrogen shift, and if the pathway $\mathbf{b}$ is favored over pathway a.

\footnotetext{
*These deprotonation reactions are highly exothermic and fast. Note that even very slow deprotonation reactions show no kinetic isotope effects in our experiments: the deprotonation of $\mathrm{CD}_{3} \mathrm{CO}^{+}$and $\mathrm{CH}_{3} \mathrm{CO}^{+}$by acetone occurs at an efficiency of only $5 \%$, but no rate difference was observed.
}

\section{Conclusions}

The examination of the gas-phase reactions of bases with the radical cations of $\mathrm{CD}_{3} \mathrm{CH}_{2} \mathrm{COOCH}_{3}$ and $\mathrm{CII}_{3} \mathrm{CII}_{2} \mathrm{COOCD}_{3}$ demonstrates that isomerization of the long-lived (>0.5-s), nonfragmenting $\mathrm{CH}_{3} \mathrm{CH}_{2}$ $\mathrm{COOCH}_{3}^{+\cdot}$ to $\mathrm{CH}_{3} \mathrm{CH}-\mathrm{C}^{+}(\mathrm{OH}) \mathrm{OCH}_{3}^{+\cdot}$ occurs by two competing pathways. Both pathways are initiated by a 1,4-hydrogen shift to the carbonyl oxygen. The hydrogen atom can originate either from the acid or the alcohol moiety. The former pathway is likely to be favored.

These experimental findings are supported by $a b$ initio molecular orbital calculations carried out at UMP2 $/ 6-31 G^{* *} / / \mathrm{UHF} / 6-31 \mathrm{G}^{* *}+$ ZPVE and UMP2 $/ 6-31 G^{* *}+$ ZPVE levels of theory. Both of the possible 1,4-hydrogen shifts in $\left.\mathrm{CH}_{3} \mathrm{CH}_{2} \mathrm{ClO}\right) \mathrm{OCH}_{3}^{+}$. are highly exothermic (by $16-20 \mathrm{kcal} / \mathrm{mol}$ ). These reactions are associated with energy barriers (10-14 $\mathrm{kcal} / \mathrm{mol}$ at the UMP2 $/ 6-31 \mathrm{G}^{* *}+$ ZPVE level) that are comparable to those calculated earlier by others for 1,4-hydrogen atom shifts in the radical cations of methyl acetate [6b] $(11 \mathrm{kcal} / \mathrm{mol}$ at the UMP2 $/ 6$ $31 G^{*} / / \mathrm{UHF} / 3-21 \mathrm{G}+\mathrm{ZPVE}$ level) and methyl formate $[4 \mathrm{c}](10 \mathrm{kcal} / \mathrm{mol}$ at the $\operatorname{QCISD}(\mathrm{T}) / 6$ $311 G^{* *} / / \mathrm{UHF} / 6-31 \mathrm{G}^{*}+$ ZPVE level). However, the barrier associated with the 1,4-hydrogen shift from the acid moiety was found to be somewhat lower than that associated with the 1,4-hydrogen shift from the alcohol moiety (by $4 \mathrm{kcal} / \mathrm{mol}$ ). This explains the favored formation of the more stable intermediate ${ }^{\circ} \mathrm{CH}_{2}$ $\mathrm{CH}_{2} \mathrm{C}^{+}(\mathrm{OH}) \mathrm{OCH}_{3}$ (3). Formation of this intermediate likely is followed by a slightly endothermic 1,5 -hydrogen shift $(\Delta H \simeq+4 \mathrm{kcal} / \mathrm{mol})$ to yield $\mathrm{CH}_{3} \mathrm{CH}_{2} \mathrm{C}^{\prime}(\mathrm{OH}) \mathrm{OCH}_{2}$ (2). A highly exothermic 1,4hydrogen shift $(\Delta H \simeq-16 \mathrm{kcal} / \mathrm{mol})$ in this ion yields $\mathrm{CH}_{3} \mathrm{CH}=\mathrm{C}^{+}(\mathrm{OH}) \mathrm{OCH}_{3}^{+\cdot}$ in a reaction that overall is exothermic by $32 \mathrm{kcal} / \mathrm{mol}$.

\section{Acknowledgments}

The Academy of Finland, University of Joensuu, and the Finnish Chemical Society, as well as the National Science Foundation (CHE-9409644), are thanked for financial support of this work.

\section{References}

1. Benoit, F. M.; Harrison, A. G.; Lossing, F. P. Org. Mass Spectrom. 1977, 12, 78.

2. Hammerum, S. Mass Spectrom. Rev. 1988, 7, 123, and references therein.

3. Bouchoux, G. Mass Spectrom. Rev. 1988, 7, 1, and references therein.

4. (a) Villeneuve, S.; Burgers, P. C. Org. Mass Spectrom. 1986, 21 , 733; (b) Flammang, R.; Plisnier, M.; Nguyen, M. T.; Vanquickenborne, L. C. Chem. Phys. Lett. 1991, 393; (c) Smith, B. J.; Nguyen, M. T.; Radom, L. I. Am. Chem. Soc. 1992, 114, 1151.

5. Leeck, D. T.; Stirk, K. M.; Zeller, L. C.; Kiminkinen, L. K. M.; Castro, L. M.; Vainiotalo, P.; Kenttämaa, H. I. I. Am. Chem. Soc. 1994, 116, 3028, and references therein.

6. (a) Burgers, P. C.; Holmes, J. L.; Hop, C. E. C. A.; Terlouw, J. K. Org. Mass Spectrom. 1986, 21, 549; (b) Heinrich, N.; 
Schmidt, J.; Schwarz, H.; Apeloig, Y. I. Am. Chem. Soc. 1987, $109,1317$.

7. Rideoul, J.; Symuns, M. C. R. I. Chem. Soc. Perkin Trans. II 1968,625 , and references therein.

8. Holmes, J. L.; Lossing, F. P. J. Am. Chem. Soc, 1980, 102, 1591.

9. Lias, S. G.; Bartmess, J. E.; Liebman, J. F.; Holmes, J. L.; Levin, R. D.; Mallard, W. G. J. Phys. Chem. Ref. Data 1988, 17, Suppl. 1.

10. Marshall, A. G.; Wang, T.-C. L.; Ricca, T. L. J. Am. Chem. Soc. $1985,107,7983$
11. (a) Su, T.; Chesnavich, W. J. I. Chem. Phys. 1982, 76, 5183; (b) Bartmess, J. E.; Georgiadis, R. M. Vacuum 1983, 33, 149; (c) Stirk, K. G.; Kenttämaa, II. I. J. Am. Chem. Soc. 1992, 96, 5272.

12. Clinton, R. O.; Laskowski, S. C. J. Am. Chem. Soc. 1948, 70, 3135

13. Hemberger, P. H.; Kleingeld, J. C.; Levsen, K.; Mainzer, N.; Mandelbaum, A.; Nibbering, N. N. M.; Schwarz, H.; Weber, R.; Weisz, A.; Wesdemiotis, C. J. Am. Chem. Soc. 1980, 102, 3736. 